\title{
A note concerning the text, editions, and authorship of the 1660 Standard Confession of the General Baptists
}

\author{
Stephen R. Holmes \\ St Mary's College, University of St Andrews, Scotland
}

\begin{abstract}
:
The, hitherto anonymous, Confession prepared by a General Baptist assembly in London in 1660 became the 'Standard Confession' of the denomination following its adoption at the General Assembly of 1663; re-issued by Thomas Grantham in 1678, and re-affirmed repeatedly by the General Assembly through the 1690s, it is unquestionably the most significant symbolic document of the English General Baptists. I argue on the basis of textual evidence that the standard editorial history is wrong: there were two editions in 1660 , but no new edition in 1663. I further argue that there is good reason to assume that the authors of the Confession were Matthew Caffyn, Joseph Wright, and John Parsons, senior.
\end{abstract}

Keywords: General Baptists; Matthew Caffyn; Joseph Wright; John Parsons; confessional documents. 
Although we have no minutes, there is documentary evidence of an assembly of the General Baptists held in March 1660, ${ }^{1}$ which authorized the writing of a confession of faith. ${ }^{2}$ The context was the continuing political uncertainty following Oliver Cromwell's death, and more immediately the arrival of George Monck into London at the head of an army in early February; it seems unlikely that it was then clear that Monck intended to restore the monarchy (the Declaration of Breda was issued in early April, and Monck had seemingly successfully concealed his intentions until that point), but it was without question a time of considerable political uncertainty. In this situation there was an obvious need for any group that might be regarded - or constructed - as disloyal or dangerous to justify itself; the significance of this context can be seen in the ending of the 1660 Confession, a hot denial of rumours that Baptists were storing up weapons, accounts of which had apparently already reached Parliament. ${ }^{3}$

The Confession was re-affirmed at the General Assembly of 1663, at which point it became the 'Standard Confession' of the General Baptists. Thomas Grantham issued a slightly altered edition in 1678 (presumably as a rival to the Orthodox Creed, with which he was clearly unhappy ${ }^{4}$ ); in response to the queries over Matthew Caffyn's orthodoxy which consumed the Assembly through the 1690s, the Standard Confession was once again reissued, although with claims from Caffyn's opponents that it had been edited to make his views acceptable. ${ }^{5}$ There are many later editions, and it is without doubt the most lastingly significant of the General Baptist confessions.

The Confession was signed by forty leaders in 1660, but its authorship is unstated. McGlothlin proposed Thomas Grantham as the composer, presumably on the basis of the 1678 edition; Lumpkin gives compelling reasons for rejecting this ascription. ${ }^{6}$ He instead suggests William Jeffrey of Kent as the main author, on the basis of the influence amongst the denomination of his 1660 work, The Whole Faith of Man; he also proposes that Matthew Caffyn of Sussex and Thomas Monck of Hertfordshire may have been involved.

In this brief note I intend, first, to sketch a history of the seventeenth-century editions of the Standard Confession, noting the points of variation, and, second, to propose a theory

\footnotetext{
${ }^{1}$ The evidence takes the form of a written note on a text of the confession; see W.T. Whitley, Minutes of the General Assembly of the General Baptist Churches in England (London: Baptist Historical Society, 1909) (2 vols), I.10.

${ }^{2}$ Lumpkin is the most convenient source for the text of the Standard Confession; William L. Lumpkin, Baptist Confessions of Faith (Valley Forge: Judson Press, 1969), pp. 224-235; Whitley offers a critical edition of the 1660 edition with notes of amendments made by Thomas Grantham for an edition of 1678; see below on editions.

${ }^{3}$ Whitley, Minutes, I.20-1; cf Lumpkin, Confessions, p. 234.

${ }^{4}$ See the letter of Grantham to Thomas Monck, Stephen Dagnall and others who signed the Orthodox Creed preserved in Anon., A Vindication of the Antient General Assembly... (London: 1704), pp. 53-56, which lists fifteen points of disagreement.

${ }^{5}$ See Christopher Cooper, The Vail Turn'd Aside...(London: 1701), p. 120 for this charge; it seems false (unless referring to Grantham's elucidation of the article concerning Christology), as I shall demonstrate later.

${ }^{6}$ Lumpkin, Confessions, p. 221
} 
concerning authorship on the basis of documentary evidence which, although not irrefutable, is, I shall argue, strong.

There were in fact two printings of the Confession in 1660 one of March 15 (dated by handwritten note on the British Library copy), which is a pamphlet of $12 \mathrm{pp} ;{ }^{7}$ the other, dated similarly (by handwritten note on the British Library copy) to July 26, a single large sheet. ${ }^{8}$ The second printing was presented to the King by Thomas Grantham and another messenger in July. The two texts are not quite identical, but the variations are merely orthographic or typographic, as the following comparison shows (underlining added to indicate differences; italics original):

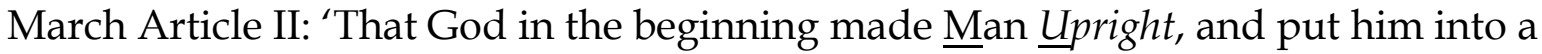
state and condition of Glory, without the least mixture of misery, from which he by transgression fell, and so came into a miserable and mortal estate, subject unto the first death, Gen. 1.31. Eccles. 7.29 Gen. 2.17 3.17,18,19.'

July Article II: 'That God in the beginning made man upright, and put him into a state and condition of Glory, without the least mixture of misery, from which hee by transgression fell, and so came into a miserable and mortall estate, subject unto the first death, Gen. 1.31. Eccles. 7.29 Gen. 2.17. 3.17,18,19.'

The July text makes one - fascinating - addition of substance: below the list of signatories is the claim that the confession is '[o]wned and approved by more than 20000 '. No doubt this figure was deliberately optimistic to impress the King; if it was even remotely correct, however, it is evidence of extraordinary growth during the previous two decades, and of sad stagnation for the next half-century; Evans plausibly estimated the number of hearers attending General Baptist congregations in 1718 as only $19000 .^{9}$

We have no minutes of the 1663 Assembly, and so no direct witness to the text there; our evidence for the Confession's adoption comes from Grantham's 1678 edition, which is headed 'A Brief Confession, or Declaration of Faith set forth by an Assembly of Messengers, Elders and Brethren of the Baptized Churches, An. 1663'.10 This raises an interesting textual problem: Grantham states that he has added 'a few explanatory supplements, and the testimony of many of the ancient writers of Christianity'. The latter material, characteristic of Grantham's concern to demonstrate seventeenth-century Baptists as standing within the historic traditions of the apostolic church, is easy to identify: a section entitled 'The witness of the Ancients' is appended to each article. The former additions are further explained as follows: 'I have also omitted some things which in some of those Articles was added upon particular occasion, and not so precisely concerning matter of Doctrine. I have also explained some few passages for the better understanding of the Reader. ${ }^{11}$ Where we find divergence between the 1660 text and

\footnotetext{
${ }^{7}$ A Brief Confession or Declaration of Faith... (London: Printed by G.D. for F. Smith, 1660) Wing B4559.

${ }^{8}$ A Brief Confession or Declaration of Faith... (London: Printed by F. Smith, 1660) Wing B4560.

${ }^{9}$ So Raymond Brown, The English Baptists of the Eighteenth Century (London: Baptist Historical Society, 1986), p. 16.

10 Thomas Grantham, Christianismus Primitivus... (London: Francis Smith, 1678) II.62-74 for the Confession; p. 62 for the quotation.

${ }^{11}$ Grantham, Christianismus..., p. 74.
} 
Grantham's text, then, are we to ascribe it to a 1663 edition to which he had access, or to Grantham's own editorial work?

Whitley chooses the latter course, and so implies that the 1663 text was identical to the 1660 text;12 Lumpkin asserts a 1663 revision of the 1660 text, although offers no basis for this assertion. ${ }^{13}$ Estep also suggests a 1663 revision, presumably following Lumpkin. ${ }^{14}$ The 1691 edition ${ }^{15}$ is of some help in proposing a solution to this conundrum; it appears, with only three exceptions, to be identical to the 1660 edition (indeed, the orthographic evidence suggests it is derived from a copy of the March 1660 edition rather than the July edition). It is described as a 'reprint,' and was intended to be such by the General Assembly; although they were clearly aware of Grantham's amendments, these have, in every case except one, been ignored. A full synoptic comparison is beyond the scope of my work here, but to offer only one indicative line of evidence, in Art. I 1660 speaks of God as 'unwordable in all his Attributes', a reading preserved in 1691, but altered to 'unsearchable in all his attributes' by Grantham. It seems implausible that, were they willing to amend their source text, the 1691 Assembly should have preferred 'unwordable' to 'unsearchable'.

In one case however, specified in the 1691 Assembly minutes, they did choose to follow Grantham. In Art. III, the 1660 edition speaks of Christ in the following terms: 'as truly Davids Lord as Davids root, as Davids Son, and Davids Off-spring' Grantham and the 1691 edition, by contrast, share a different reading: 'Being the true Lord and root of David, and also his Son and Offspring according to the flesh...' (even the pattern of italicisation is identical in the two texts). The 1691 minutes record an agreement that the Confession was 'owned \& acknowledged' with 'no man Disalowing with the Explicatition [sic] made by Brother Grantham in the 3d. Article'; they later record a decision to reprint the Confession 'with the above said Explication of the sd. Article'.16

The second change from 1660 is the omission of the closing plea concerning the rumours of sedition amongst Baptists; I presume the 1691 Assembly regarded this as not being a part of the Confession, but as an added plea to the King; Grantham also omits it (I assume it is what is meant by his note, quoted above, that he omitted some material on the basis that it was occasional not doctrinal; which, if correct, implies that this material was included in the edition Grantham worked from).

The last difference between the 1660 edition and the 1691 edition is the list of signatories. There are twenty-seven names under a heading 'These names since added'; fifteen of those correspond to those who signed the 1691 minutes 'In behalfe of the Rest', suggesting that this list is indicative of those present at the 1691 General Assembly who had not

\footnotetext{
12 Whitley, Minutes, p. 10

${ }^{13}$ Lumpkin, Baptist Confessions, p. 223.

14 William Roscoe Estep, 'Baptists and authority : the Bible, confessions, and conscience in the development of Baptist identity.' Review E Expositor 84 (1987), pp. 599-615, p. 606.

${ }^{15}$ A Brief Confession or Declaration of Faith... (London: 'reprinted 1691'); Wing T2726; like the July 1660 edition, it is printed on a single large page.

16 Whitley, Minutes, I.30-31.
} 
previously signed the Confession. The first list, by implication the original signatories, shows several divergences from the 1660 list, as follows:

On 1691 list, but not 1660 list: Benjamin Bowyer, William Fletcher, Christopher Miles, John Dewberry, Richard Hobbs, Randolph Rooper, Henry Baldwin, Robert Martin, Thomas Slater Richard Newberry; and John Bennett.

Altered between 1660 list and 1691 list: Jonathan Gennings becomes Jonathan Jennings; Joseph Keeich becomes Joseph Keach; and William Chandwel becomes William Chandwell.

On 1660 list, but not 1691 list: William Russel [sic], John Wells, William Raph, Richard Bowin, Nicholas Newberry, and Thomas Smith.

The removal of the name of William Russell, in particular, might invite conspiracy theories: he was the leading opponent of the General Assembly through the 1690s, and a founder-member of the rival General Association; that said, it is difficult to find a similar reason for the omission of any of the others whose names are missing in 1691, and the fact that those whose names were added, and of whom we have any record, were active leaders in the 1660s suggests an alternative explanation, that the 1691 list reproduces the signatories of the 1663 Confession (and so, presumably, also reproduces the membership of the 1663 Assembly). If this is right, then the 1691 edition is, with the exception of Grantham's alternative wording on Christology, a reprint of the 1663 edition, and so we may assert that the 1663 edition was identical to the March 1660 edition, on the basis of the textual comparisons noted above.

Indeed, I think we may go further and query the existence of a 1663 edition; our evidence is merely that the Confession was approved and adopted by the 1663 General Assembly; there is no evidence of a printing of the Confession in 1663 and two lines of argument perhaps make it seem unlikely. First, the addendum concerning sedition just noted: Grantham's comment about omitting this is evidence that it was present in the text agreed by the 1663 Assembly, but reviving rumours of Baptist sedition from three years earlier in a reprint of this material would have been a strange thing to have done in 1663, particularly given the context of Venner's rebellion and the alleged 'Northern Uprising'. Recalling to political memory that there had been previous accusations of sedition against Baptists would have been rather less than politic. It seems most likely, therefore, that they simply approved a copy of the March 1660 printing. Second, given the textual instability between the two 1660 printings, the idea that a perfect replica of the March 1660 edition was printed in 1663 seems implausible; a new edition would almost inevitably show some minor variations in orthography, italicisation, or punctuation. I propose, then, that there was in fact no 1663 edition of the Confession. ${ }^{17}$

None of this detail helps in establishing the authorship of the Confession, but there is an interesting piece of evidence in an anonymous 1704 text entitled $A$ Vindication of the

\footnotetext{
17 This assumes the same printer was employed; Francis Smith seems to have printed virtually all General Baptist publications in London in the period, so this assumption is plausible.
} 
Antient General Assembly from the False Imputations of the Russelites... (the 'Russelites' being members of the General Association, and followers of William Russell). ${ }^{18}$ The anonymous author reviews the long history of doctrinal accusation and acrimony surrounding Matthew Caffyn which erupted in the separation of the General Association from the General Assembly in 1696; reaching back into the history at one point he says:

And whereas the then present Juncture of National Affairs called, as they thought, for a publick Confession of Faith, 'twas agreed by an Assembly then met, that Joseph Wright, Matthew Caffen and John Parsons should withdraw themselves some time from the Assembly Affairs, and draw up something of that Nature, withal giving them direction, so to draw up that Article wherein they differed, that both Parties might freely subscribe thereunto, which they perform'd to the intire satisfaction of the Assembly. ${ }^{19}$

(The context of this comment is that Wright (of Maidstone) and Caffyn had been involved in doctrinal dispute; and the author is making the case that such disputes need not be causes of division.)

The writer gives no indication of when this event happened. Wright and Caffyn are both active as messengers for the whole second half of the seventeenth century. There are two leaders called John Parsons, senior and junior, both of whom signed the 1660 Confession; John Parsons senior had been active through the 1650s; John Parsons junior remained significant into the eighteenth century. The coincidence of the three names, therefore, does not locate the event described any more exactly than sometime between 1654 (when Caffyn became a Messenger) and 1703 (when Wright died). The 1704 writer is clearly recalling an event some distance in the past, so we might push the latest possible date back to before 1693, the date of a secession from the General Assembly, which he regards as the starting point of the dispute he is addressing. This still gives us a period of forty years, however.

That said, the only extant record we have of a General Baptist Assembly requiring a Confession to be drawn up is in 1660, and Caffyn, Wright, and (both) Parsons are all signatories to the 1660 Confession. Further, the description of the occasion, of a particular national crisis being judged to require a confession, does fit 1660 well. There are, of course, many other dates that it would also fit in those eventful decades: the passing of the Clarendon Code in 1662; the crises concerning Charles' potential conversion to Catholicism; the Glorious Revolution of $1688 ;. .$. But we do not have any record of a confession being drawn up in relation to any moment of crisis except 1660. Finally, I note that the matter of dispute between Caffyn and Wright would seem to have been Caffyn's distinctive 'heavenly flesh' Christology, ${ }^{20}$ probably derived from Menno Simons, which asserted that the human nature of Jesus Christ was not derived from Mary, but created $a b$ novo in heaven; the odd phrasing about Christ being David's Lord and David's root, David's son and David's offspring, that Grantham and the 1691 Assembly found it

\footnotetext{
${ }^{18}$ The publication details simply read 'Printed in the Year M.DCC.IV.'

19 Vindication..., p. 57.

${ }^{20}$ I have a forthcoming essay describing this in detail, and suggesting that the standard history, which has Caffyn first denying Christ's humanity and later becoming Arian, is inaccurate in several respects. I take the view that his principles were fairly consistent through his life, never involved any querying of Christ's true humanity, and are not properly described as Arian, although his Trinitarian theology is at least unusual.
} 
necessary to clarify, might very plausibly be regarded as a compromise formula hammered out around that debate.

Wright and Caffyn were both active as Messengers already in the mid-1650s, and so would have been appropriate choices to write a Confession at the 1660 Assembly; Parsons (senior) had been a leader for some years at that point also. The anonymous writer who records this story is extremely partisan on Caffyn's side, but is also clearly intimately familiar with the history of the dispute he narrates; in the absence of evidence to the contrary it seems appropriate to accept his account as historically accurate. If it is, it fits the writing of the 1660 Confession well, and there is no other event known to us that it could possibly match. So I propose that the 1660 Standard Confession of the General Baptists was written by Matthew Caffyn, Joseph Wright, and John Parsons, senior. 